\title{
Economic valuation of plant diversity storage service provided by Brazilian rupestrian grassland ecosystems
}

\author{
Resende, FM. , Fernandes, GW. and Coelho, MS. \\ Ecologia Evolutiva \& Biodiversidade - DBG, CP 486, ICB - Universidade Federal de Minas Gerais, \\ 30161-970 Belo Horizonte, MG, Brazil \\ e-mail: gw.fernandes@gmail.com \\ Received July 16, 2012 - Accepted November 12, 2012 - Distributed November 29, 2013
}

\begin{abstract}
The rupestrian grassland ecosystems provide various goods and services to society and support a significant amount of biological diversity. Notably the rich plant diversity has high levels of endemism and a variety of uses among the local communities and general society. Despite the socio-ecological importance of these ecosystems, they are subjected to significant anthropogenic pressures. The goal of this study is to perform economic valuation of the plant diversity storage service provided by rupestrian grassland ecosystems to provide grounds for the development of conservation policies and encourage sustainable practices in these ecosystems. Given the intense human disturbances and unique flora, the Serra do Cipó (southern portion of the Espinhaço Range in southeast Brazil) was selected for the study. We estimate the monetary value related to the plant diversity storage service provided by the study area using the maintenance costs of native plants in the living collections of the botanical garden managed by the Zoobotanical Foundation - Belo Horizonte (located $97 \mathrm{~km}$ from Serra do Cipó). The plant diversity storage value provided by Serra do Cipó ecosystems is significant, reaching US\$25.26 million year ${ }^{-1}$. This study contributes to the development of perspectives related to the conservation of rupestrian grassland ecosystems as well as others threatened tropical ecosystems with high biodiversity
\end{abstract}

Keywords: biodiversity, conservation, economic valuation, valuation methods.

\section{Valoração econômica do serviço de estocagem da diversidade de plantas fornecido pelos ecossistemas de campos rupestres brasileiros}

\section{Resumo}

Os ecossistemas de campos rupestres fornecem diversos bens e serviços à sociedade, além de abrigar uma significativa diversidade biológica. Particularmente, a rica biodiversidade vegetal apresenta altas taxas de endemismo e uma grande variedade de usos entre a comunidade local e a sociedade como um todo. Apesar da importância sócio-ecológica desses ecossistemas, eles estão submetidos a significativa pressão antrópica. O objetivo desse estudo é realizar a valoração econômica do serviço de estocagem da diversidade de plantas fornecido pelos ecossistemas de campos rupestres para fornecer subsídios para o desenvolvimento de políticas conservacionistas e estimular práticas sustentáveis nesses ecossistemas. Diante dos intensos distúrbios antrópicos e sua flora única, a Serra do Cipó (porção sul da Cadeia do Espinhaço, Sudeste do Brasil) foi selecionada para este estudo. Estimamos o valor monetário relacionado ao serviço de estocagem da diversidade de plantas fornecido pela área de estudo, utilizando os custos de manutenção de plantas nativas em coleções vivas do jardim botânico da Fundação Zoo-Botânica de Belo Horizonte (localizado a 97 km da Serra do Cipó). O valor do estoque da diversidade de plantas fornecido pelos ecossistemas da Serra do Cipó é significativo, atingindo US $\$ 25,26$ milhões ano $^{-1}$. Esse estudo contribui para o desenvolvimento de perspectivas relacionadas à conservação dos ecossistemas de campos rupestres assim como outros ecossistemas ameaçados e com alta biodiversidade nos trópicos.

Palavras-chave: biodiversidade, conservação, valoração econômica, métodos de valoração.

\section{Introduction}

Changes in biological diversity negatively impact ecosystem processes (Chapin et al., 2000; Loreau et al., 2002), and the benefits and services provided by natural ecosystems are diminished by environmental degrada- tion. Ecosystems benefit society in numerous ways, including by providing i) provisioning services, such as those related to food, water, wood, and fiber; ii) regulatory services, such as the regulation of flooding, disease, climate, and air and water quality; iii) cultural services, such as recreation, aesthetic pleasure, and spiritual satis- 
faction; and iv) support services, such as soil formation, photosynthesis, and nutrient cycling (MA, 2003). Although these services are extremely important to human welfare, they remain undervalued by society (Daily, 1997). Approximately $60 \%$ of these ecosystem services provided by biosphere have been degraded over the last 50 years, and human impacts are considered to be the main cause of this decline (MA, 2005).

Valuation of ecosystem services may help to address the current biodiversity crisis. Various methods have been developed to measure the economic contributions of natural ecosystems (Daily, 1997; CBD, 2007), allowing monetary values to be addressed to these ecosystem services (e.g., Balmford et al., 2002; Costanza et al., 1997). Given the incredible diversity of species and the broad range of services provided by ecosystems, these concepts remain under-researched in many parts of the tropical world, where high levels of biodiversity (and the associated arrays of ecosystem services) are subjected to significant anthropogenic pressures.

Among the tropical biomes, the Brazilian savanna (Cerrado) is one of the most threatened. Despite the high biodiversity levels (there are more than 11,600 species taking into account only the native plants) (Mendonça et al., 2008), the Cerrado has been transformed at a rapid pace (Klink et al., 2008). More than half of the Cerrado's area has been lost in only four decades (Sano et al., 2001; Klink and Machado, 2005). Whereas Cerrado areas located on relatively flat terrain have been devastated (primarily by livestock and agricultural intensification), patches of Cerrado on rocky outcroppings and mountains have been impacted at lower rates.

Rupestrian grasslands ecosystems occur at high altitudes (generally above 900 metres above sea level) and are found on areas characterised by shallow soils with high acidity and low nutritional levels and are primarily associated to the Cerrado located in the Espinhaço Range, eastern Brazil (Giulietti et al., 1997; Benites et al., 2007). The plant community in the rupestrian grasslands is mainly composed of an herbaceous stratum with small shrubs and subshrubs which supports high biodiversity and endemism levels (Giulietti et al., 1997). The most common plant families in rupestrian grasslands include Cyperaceae, Poaceae, Asteraceae, Eriocaulaceace, Velloziaceae, and Melastomataceae (Giulietti et al., 1987). More than $30 \%$ of the species found in these rupestrian grasslands are endemic, while some taxa display a rate of endemism that exceeds $80 \%$ (Giulietti et al., 1987, 1997). During sampling of a ca. $200 \mathrm{~km}^{2}$ corridor composed mostly of rupestrian grasslands in Serra do Cipó, about 1,600 plant species were reported (Giulietti et al., 1987).

The flora of Serra do Cipó has a variety of uses among the rural communities close to the area and also for society in general. Reports of the use of these plants date back to the early colonisers. The plants found in the region are used as a source of natural fibres (e.g., Guadua sp. and Attalea oleifera), food (e.g., Caryocar brasiliensis, Acrocomia aculeata), resins and oils, and for ornamental purposes (ICMBio, 2009). Ranieri et al. (2003) reported the potential use of the genus Lavoisiera (Melastomataceae) as an ornamental species, and dozens of other species are currently being propagated to meet consumer demand, whereas Brandão et al. (1996) listed 134 medicinal plant species in the rupestrian grasslands of Serra do Cipó (Ventura et al., 2007). Therefore, despite not having been the focus of any previous valuation study, the rupestrian grasslands provide a valuable service of storing rich plant diversity, a source of several benefits to local communities and society in general.

The value of ecosystem services can be estimated by assessing the cost to replicate a particular service under artificial conditions. Considering the maintenance of plant species, the use of live plant collections from botanical gardens stands out as a well-established global practice and is useful for ex situ plant maintenance (e.g., Mistretta et al., 1991; Stevens 2007); there are over 6 million live plants in 2,500 botanical gardens worldwide (Golding et al., 2010). The objective of this study is to perform the economic valuation of the plant diversity storage service provided by rupestrian grasslands ecosystems. Given its diverse and unique flora, Serra do Cipó was selected as the study area for this research. Hence, we estimate the monetary value related to the plant diversity storage service provided by the study area using the maintenance costs of native plants in the living collections of the botanical garden managed by the Zoobotanical Foundation - Belo Horizonte (located $97 \mathrm{~km}$ from the Serra do Cipó). We expect that determining the relative value of the plant diversity storage service will encourage conservation and sustainable practices in Serra do Cipó and serve as a model for other ecosystems in need of conservation in the tropics.

\section{Methods}

\subsection{Study area}

Serra do Cipó is located in the central region of Minas Gerais state, southeast Brazil, in the southern portion of the Espinhaço Range. The Espinhaço Range is a predominantly quartzitic range of mountains that is approximately $1,100 \mathrm{~km}$ in length and extends from the city of Ouro Branco in Minas Gerais state to the northern boundary of Bahia state. Serra do Cipó divides the São Francisco river basin to the west and the Rio Doce river basin to the east. Following the Köppen (1931) classification, the predominant climate is Cwb type at a tropical altitude with a pronounced dry season and wet summers. The annual average rainfall ranges from 1,300 to $1,600 \mathrm{~mm}$ and is concentrated between November and January (Madeira and Fernandes, 1999).

The vegetation of Serra do Cipó is primarily influenced by components from two major Brazilian biomes: Atlantic rain forest (on the east side) and Cerrado (on the west side). The Cerrado is represented primarily by rupestrian grasslands, which cover more than half of Serra do Cipó's area and support most part of the plant di- 
versity described to the whole region (Madeira et al., 2008). Other formations are also found in Serra do Cipó, such as Cerrado sensu stricto, gallery forests, and seasonally dry tropical forests on limestone outcrops (Giulietti et al., 1987; Coelho et al., 2012). Serra do Cipó ecosystems support a highly complex vegetation matrix that sustains high biodiversity and endemism levels. Although the high levels of biodiversity in Serra do Cipó have been described in many studies, the underlying conditions that produce such diversity have yet to be determined, as the soil matrix, topography, and climate may all play a role (Carvalho et al., 2012; Giulietti et al., 1987).

\subsection{Economic valuation}

To estimate the value of the plant diversity storage at Serra do Cipó, we calculated the maintenance cost of native plants in the living collections of the botanical garden managed by the Zoobotanical Foundation - Belo Horizonte (BG-ZBF). The BG-ZBF is located ca. $100 \mathrm{~km}$ of Serra do Cipó, in the city of Belo Horizonte, and is nationally recognised for its contributions related to the cultivation of native plant species and their conservation. The BG-ZBF is a reference centre for botanists and maintains a large collection of flora endemic to the state of Minas Gerais, including significant living plant collections. The stock of living collections is comprised of approximately 3,300 specimens, including plants from rupestrian grasslands, succulents, Araceaes, and bromeliads, among other species. The BG-ZBF's collection of plants from rupestrian grasslands consists of various taxonomic groups, such as Xyris, Cipocereus, Rhynchospora, Vellozia, Dyckia, Laelia, Lavoisieira, Coccoloba, Lychnophora (Da Costa, 2004). The BG$\mathrm{ZBF}$ was considered to offer an adequate and conservative source of data for this study due the practical knowledge of BG-ZBF in the maintenance of plants from rupestrian grasslands, and its proximity from Serra do Cipó. If a different botanical garden or institution were chosen the costs to maintain the plant species would have been much higher due to the increased distance, and lack of know-how to maintain the collection, which would ultimately lead to increased value of the ecosystem service evaluated.

For cost estimation, we conducted several technical visits to the BG-ZBF in 2010. Information was obtained from the Coordination Section of Applied Botany and other members of the technical team at the BG-ZBF. We also consulted documents used by managers, including a survey of the property under the stewardship of the BGZBF and the supplies requested by the BG-ZBF for 2010 . Primarily we calculated the costs in Brazilian currency (Real - R\$) and then we converted into 2010 US\$ using the exchange rate of 1 US $\$=\mathrm{R} \$ 1,75$. We only evaluated activities strictly linked to the living collections; therefore, the specific costs of other activities (e.g., maintenance of the herbarium and other collections) were not taken into account.
We identified the main costs associated with the maintenance of the living collections to determine the annual maintenance cost of one specimen in the nursery. To this end, we analysed a wide range of variables, including expenses related to i) specimen acquisition in the field (e.g., fuel expenses and costs/day); ii) the physical structure used for packaging plants; iii) area associated with technical/administrative activities and nurseries for living collections, iv) acquisition of permanent material (e.g., furniture and electronic equipment); v) acquisition of supplies (e.g., fertilisers, pesticides, and garden tools); vi) human resources (e.g., biologists, technicians and gardeners); vii) electricity, communication and water consumption (see Appendices 1-7 for the evaluation parameters and additional information regarding how the calculations were performed for different categories Appendices are available only in the electronic version).

In this study, we also considered the opportunity cost of the values related to the maintenance of the living collections using the 2010 annual mean value $(9.93 \%)$ of the basic interest rate - the SELIC rate - decided by the Brazilian Central Bank.

After calculating the maintenance costs for one plant specimen in the living collections, we inventoried the plant species richness from Serra do Cipó based on an extensive literature review (analysis of 544 scientific papers published between 1831 and 2005) carried out by Madeira et al. (2008). We separated the total species richness into the following four categories: i) plants endemic to Serra do Cipó, ii) plants endemic to the Espinhaço Range, iii) plants identified as threatened in Minas Gerais, and iii) plants not endemic to the Espinhaço Range and not threatened. Among the 2,157 plant species found in the study region, 72 are endemic to Serra do Cipó; 86 are endemic to Espinhaço Range; 113 are listed as threatened in Minas Gerais state; and the remaining 1,958 are widely distributed and are not threatened (Madeira et al., 2008). The calculations were performed considering the different taxonomic groups found in Serra do Cipó. Appendix 8 presents the species composition organised by taxonomic group (Appendices are available only in the electronic version).

We estimated the maintenance value for all species considering the minimum number of individuals necessary to maintain genetic variability in an isolated population without significant manipulation according to the definition of the minimum viable population theory (DeSalle and Amato, 2004). This theory suggests that a population requires at least 50 individuals (short-term maintenance) and preferably 500 (long-term maintenance) to support the conservation of genetic diversity (e.g., Franklin, 1980; Gandara and Kageyama, 1998). For species with a greater conservation value due to their conservation status and/or biogeographical characteristics (i.e., restricted range or threatened species), an upper estimate of 500 individuals was used for subsequent calculations. For native species that are not threatened and exhibit wide distribution, only 50 individuals were considered in the calculations. The population size consid- 
ered in this study is much smaller than the size of populations found in Serra do Cipó, as discussed below.

There are not sufficient available data to calculate the precise area occupied by the species in our study. A great deal of the biodiversity inventory has been conducted in areas adjacent to Serra do Cipó National Park, but much of the protected area has not been adequately sampled (Madeira et al., 2008). Nevertheless, to establish a monetary value per area unit (US\$ ha ${ }^{-1}$ ) for the plant diversity storage service, we assumed that all of the plant species from Serra do Cipó occur within the conservation unit boundaries. Serra do Cipó National Park covers an expansive area $(31,618$ hectares $)$ and supports many habitats and environment types.

\section{Results}

\subsection{Acquisition and maintenance costs}

The acquisition and maintenance costs related to a plant specimen from Serra do Cipó under ex situ conditions were approximately US\$109.95, including US\$33.92 for specimen acquisition (assuming collection was carried out in the study area) and US\$76.02 for the annual maintenance of a specimen in the collection. The largest maintenance costs are associated with human resources (US\$58.80 specimen $^{-1}$ year $^{-1}$ ), as well as the physical structure and area required (US $\$ 11.15$ specimen $^{-1}$ year $^{-1}$ ) (Table 1). The sum of these two categories represents over $90 \%$ of the maintenance expenses. Other activities, including permanent material, water consumption and communication expenses, presented relatively low values.

\subsection{Plant diversity storage value}

The annual storage value related to one plant species with the greatest conservation value (endemic and/or threatened species) was US\$54,974.03 (Table 2). This

Table 1 - Distribution of costs associated with acquisition and annual maintenance of one native plant specimen from Serra do Cipó in the living collections of the BG-ZBF related to 2010 .

\begin{tabular}{|c|c|c|}
\hline Category & & $\begin{array}{c}\text { Cost per } \\
\text { specimen } \\
\left(\text { US\$ year }{ }^{-1}\right)\end{array}$ \\
\hline Acquisition & & 33.92 \\
\hline \multirow[t]{7}{*}{ Maintenance } & $\begin{array}{l}\text { Physical structure and area } \\
\text { required }\end{array}$ & 11.15 \\
\hline & Permanent material & 1.58 \\
\hline & Supplies & 2.30 \\
\hline & Human resources & 58.80 \\
\hline & Electricity & 0.88 \\
\hline & Communication & 0.27 \\
\hline & Water consumption & 1.05 \\
\hline Total & & 109.95 \\
\hline
\end{tabular}

Table 2 - Plant diversity storage service provided by Serra do Cipó ecosystems per categories of plant diversity.

\begin{tabular}{lc}
\hline Service & $\begin{array}{c}\text { Value per one species } \\
\text { (US\$ year }\end{array}$ \\
\hline $\begin{array}{l}\text { Storage service of endemic } \\
\text { and/or threatened species }\end{array}$ & $54,974.03$ \\
$\begin{array}{l}\text { Storage service of non endemic } \\
\text { and/or not threatened species }\end{array}$ & $5,497.40$ \\
\hline
\end{tabular}

value was significantly higher than the storage value of one non endemic and/or not threatened species (US\$5,497.40).

Dicotyledoneae (1,465 species) and Monocotiledoneae (609 species) presented the greatest numbers of species in Serra do Cipó (Appendix 8) and exhibited higher storage service, with a value of US\$15,376 million attributed to the collective storage of the first group and US\$9,334 million attributed to the second (Table 3). When combined, the values of these two groups accounted for $97 \%$ of the annual plant diversity storage value provided by Serra do Cipó ecosystems.

Plants that were not restricted to Serra do Cipó and not under the threat of extinction presented a higher collective storage value (US\$10,368 million) than other groups (Table 3 ). The remaining categories of plants are listed in descending order according to their storage service value: plants threatened in Minas Gerais (US\$6,212 million), plants endemic to the Espinhaço Range (US\$4,727 million), and plants endemic to Serra do Cipó (US\$3,958 million).

Thus, the plant diversity storage value provided by Serra do Cipó ecosystems is significant, with a value of US\$25.26 million year ${ }^{-1}$ (Table 3). Considering the estimated area of species occurrence, the average value of the plant diversity storage service of Serra do Cipó is US\$799.11 $\mathrm{ha}^{-1}$ year ${ }^{-1}$. The total value attributed to the plant diversity storage service of Serra do Cipó is primarily associated with rupestrian grasslands. The greatest number of plants was found to be associated with rupestrian grasslands $(84.1 \%)$, with the remaining species originating from other Cerrado physiognomies (3.4\%) and Atlantic Rain Forest (12.5\%) (Madeira et al., 2008).

\section{Discussion}

Valuation of ecosystem services is a strategic approach to biodiversity conservation and provides important data that allows decision making to be more consistent with conservation efforts (Daily et al., 2000; Costanza, 2006; Andrade et al., 2012). In the present study, we estimated the economic value related to the plant diversity storage service provided by Serra do Cipó ecosystems. Biodiversity plays an important role in the functioning of ecosystem (Naeem et al., 1999) and in the provisioning of several ecosystem services. Some of the ecosystem services intrinsically linked with the biodiver- 


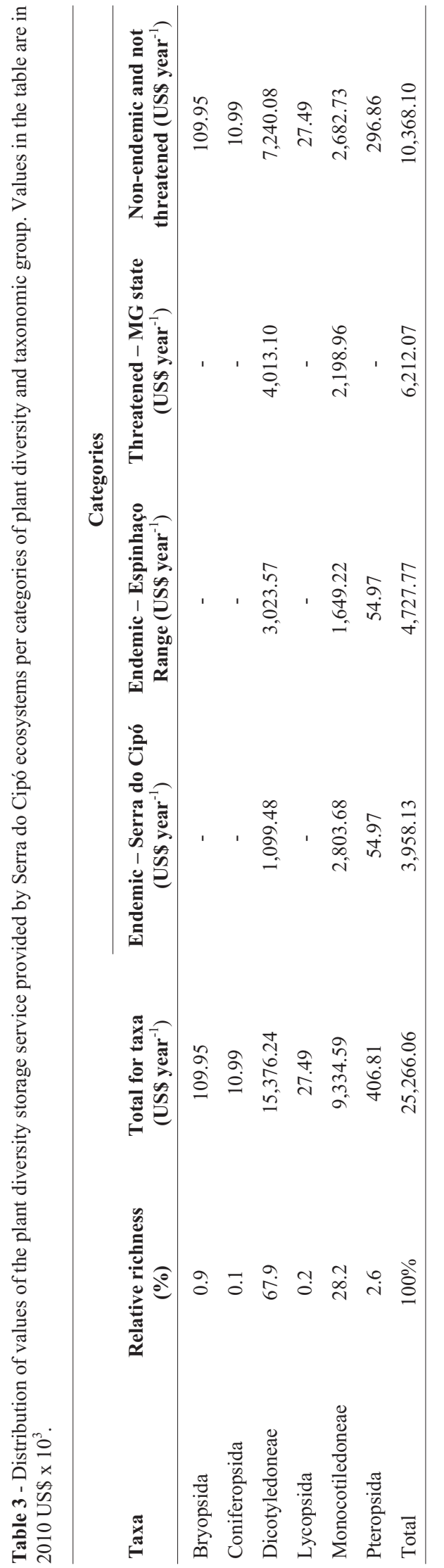

sity are related to food security (provisioning of food, pollination, pest control), provisioning of water and erosion control, provisioning of medical plants and pharmaceutical compounds and cultural values (UNEP, 2007). In this way the biodiversity storage service underpins a myriad of other ecosystem services essential for the human welfare.

Unfortunately, we have witnessed a large reduction of ecosystem services in Serra do Cipó (as well in other regions in the Espinhaço Range region), which has been caused by distinct anthropogenic pressures. In Serra do Cipó, fires are used to clear land for livestock grazing; timber is harvested for use as firewood; ornamental plants are collected; and urban expansion, highway construction, and the presence of invasive species all negatively impact the landscape (Viana et al., 2005; Madeira et al., 2008; ICMBio 2009; Barbosa et al., 2010). Now, the new mining frontier in the municipalities northern of Serra do Cipó may cause even further impacts. The anthropogenic pressures have intensified due to the proximity of Serra do Cipó to Belo Horizonte, which is the capital of Minas Gerais state and one of Brazil's largest cities. This study suggests that for every degraded hectare, an equivalent of US\$799.11 year ${ }^{-1}$ is lost by society, and this figure only considers the plant diversity storage service. Hence, other services provided by the ecosystems of Serra do Cipó, including carbon sequestration, water purification, and pollination, are omitted from this figure. Therefore, other impacts, such as road construction, mining, urban expansion, and certain forms of tourism, may incur huge losses that ought to be taken into account.

We are not aware of other research that has analysed the service value of biodiversity storage in the Brazilian context. Indeed, very few studies have assessed this service provided by natural ecosystems anywhere in the world. Although the service values are dependent on time and location (De Groot et al., 2012), Higgins et al. (1997) reported similar values for the plant diversity storage service provided by South African fynbos ecosystems. In current values (Consumer Price Index), the annual storage value of one native species calculated by Higgins et al. (1997) ranged from US\$74.72 to US\$7,472.32. Using another approach, the aforementioned authors found a value for the storage service related to one endemic species ranging between US\$37,225.76 and US $\$ 372,257.60$ (Cowling et al., 1997). Some variation in the values reported by different economic valuation studies is common in the literature and can be attributed to several reasons, including distinct ecological and socio-economic characteristics between the locations and countries and different approaches and methodology utilized in the studies (De Groot et al., 2012).

The highest values found in the present study for storage service of one endemic and/or threatened species (US\$54,974.03) reflect the higher valuation of species with the greatest importance for conservation objectives assumed in our approach. This approach assumes that ecosystems that support endemic and threatened species 
are of greater importance to society than those supporting species with a wide distribution and, therefore, under a lower threat of extinction. When endemic species go extinct, representing a unique evolutionary process, certain type of molecules and biochemical compounds are lost forever, and these qualities could have important uses in the future.

Although the total value calculated for plant diversity storage service (US\$25.26 million year ${ }^{-1}$ ) may be considered high, we argue that it is lower than the actual value of the storage services offered by Serra do Cipó. The plant population size used in the calculations (for a minimum viable population, i.e., 50 to 500 individuals/species - see Methods) is less than the size of the natural populations found in the study area. If all of the plant individuals present in Serra do Cipó were included in our calculations, the projected figures would be much higher. For example, in an area of only $1,440 \mathrm{~m}^{2}$ (equivalent to 0.14 hectares), Pereira (1994) reported finding 7,049 individuals (equivalent to $\sim 50,000$ individuals $\mathrm{ha}^{-1}$ ) when surveying the composition of the flora in Serra do Cipó's rupestrian grasslands. This density is substantially greater than that used in our study, of approximately seven individuals per hectare. Furthermore, the region most likely supports a significant number of plant species that have yet to be discovered. The vegetation of Serra do Cipó has been studied since the first half of the nineteenth century; however, expeditions often find species unknown to science. Zappi et al. (2002) estimated that between 1997 and 2002, a quarter of the new taxonomic descriptions made in Brazil came from rupestrian grasslands.

In the present study, only one biodiversity dimension was analysed for Serra do Cipó, i.e., plant diversity. If other groups of organisms were to be considered, including bacteria and fungi, the storage value of biodiversity would be extraordinary. For instance, on only two plant species (Bacharis dracunculifolia and Cocoloba cereifera), a total of 52 and 104 morphospecies of endophytic fungi were recorded, respectively (Oki et al., 2008; Fernandes et al., 2011). Moreover, recent studies have shown that Serra do Cipó ecosystems are also relevant in terms of soil microorganisms. Carvalho et al. (2012) identified forty-nine arbuscular mycorrhizal fungi species in the rupestrian grasslands from Serra do Cipó ( $41 \%$ of described species in Brazilian ecosystems and $23 \%$ of known species in the world), suggesting that the area is a hotspot for glomeromycetes.

In addition to the services already mentioned in this report (e.g., supplying fibre and food as well as ornamental and genetic resources), the ecosystems of Serra do Cipó provide other important benefits to society. The numerous headwaters located in Serra do Cipó feed into many rivers of importance in the state, such as the Santo Antônio River (Rio Doce river basin) and the Velhas River (São Francisco river basin). The Cipó River, which is the most significant water resource of Serra do Cipó, provides pure water to numerous local (human) communities. The Cipó River also acts as a biodiversity reserve for the basin of the Velhas River (ICMBio, 2009), which is severely impacted by the waste generated from the metropolitan region of Belo Horizonte. Serra do Cipó also stands out as an important natural tourist attraction (Campos et al., 2011). The demand for areas where extreme sports, camping, and adventure tourism can be conducted has attracted large numbers of domestic and foreign tourists to the region, being recreation another significant service that this region provides. Thus, the rupestrian field ecosystems provide many other benefits to society beyond the plant diversity storage calculated in this study.

The plant diversity storage service provided by Serra do Cipó ecosystem reaches a value of US\$25.26 million year $^{-1}$, and this figure could be substantially higher given that the value of other ecosystem services has yet to be investigated. We expect that our study will contribute to the development of new approaches and perspectives related to the conservation of threatened ecosystems in tropics.

\section{Acknowledgments}

We would like to thank the staff of the Botanical Garden of the Zoobotanical Foundation - Belo Horizonte, especially MSc. Miriam P. Mendonça for the useful help in the data collection. We would also like to thank the Pró-Reitoria de Pesquisa of the Universidade Federal de Minas Gerais for English editing costs, as well as Serra do Cipó National Park for logistical support. The study was supported by CNPq (403781/2012-4, 479485/20127, 457519/2012-6, 303352/2010-8, CAPES (DRCI 002/2009), FAPEMIG (RDP-00048-10, APQ-04105-10) and ComCerrado/MCT.

\section{References}

ANDRADE, DC., ROMEIRO, AR., FASIABEN, MCR. and GARCIA, JR., 2012. Dinâmica do uso do solo e valoração de serviços ecossistêmicos: notas de orientação para políticas ambientais. Desenvolvimento e Meio Ambiente, vol. 25, p. 53-71.

BALMFORD, A., BRUNER, A., COOPER, P., COSTANZA, R., FARBER, S., GREEN, RE., JENKINS, M., JEFFERISS, P., JESSAMY, V., MADDEN, J., MUNRO, K., MYERS, N., NAEEM, S., PAAVOLA, J., RAYMENT, M., ROSENDO, S., ROUGHGARDEN, J., TRUMPER, K. and TURNER, RK., 2002. Economic reasons for conserving wild nature. Science, vol. 297, p. 950-953.

BARBOSA, NU., FERNANDES, GW., CARNEIRO, MAA. and JUNIOR, LAC., 2010. Distribution of non-native invasive species and soil properties in proximity to paved roads and unpaved roads in a quartzitic mountainous grassland of southeastern Brazil. Biological Invasions, vol. 12, p. 3745-3755.

BENITES, VM., CAIAFA, AN., MENDONÇA, ES., SCHAEFER, CE. and KER, JC., 2003. Solos e vegetação nos complexos rupestres de altitude da Mantiqueira e do Espinhaço. Floresta e Ambiente, vol. 10, p. 76-85.

BRANDÃO, M., GAVINALES, ML. and LACA-BUENDIA, JP., 1996. Plantas medicamentosas de uso popular dos Campos Rupestres de Minas Gerais. Daphne, vol. 6, no. 2, p. 7-9. 
CAMPOS, RF. and FILETTO, F., 2011. Análise do perfil, da percepção ambiental e da qualidade da experiência dos visitantes da Serra do Cipó (MG). Revista Brasileira de Ecoturismo, vol. 4, no.1, p. 69-94.

CARVALHO, F., SOUZA, FA., CARRENHO, R., MOREIRA, FMS., JESUS, EC. and FERNANDES, GW., 2012. The mosaic of habitats in the high-altitude Brazilian rupestrian fields is a hotspot for arbuscular mycorrhizal fungi. $A p$ plied Soil Ecology, vol. 52, p. 9-19.

CHAPIN, FS., ZAVALETA, ES., EVINER, VT., NAYLOR, RL., VITOUSEK, PM., REYNOLDS, HL., HOOPER DU., LAVOREL, S., SALA, OE., HOBBIE, SE., MACK MC. and DÍAZ, S., 2000. Consequences of changing biodiversity. Nature, vol. 405, p. 234-242.

COELHO, MS., ALMADA, ED., QUINTINO, AV., FERNANDES, GW., SANTOS, RM., SANCHEZ-AZOFEIFA, A. and ESPIRITO-SANTO, MM., 2012. Floristic composition and structure of a tropical dry forest at different successional stages in the Espinhaco Mountains, Southeastern Brazil. Interciencia, vol. 37, no. 3, p. 190-196.

COSTANZA, R., D'ARGE, R., DE GROOT, R. S., FARBER, S., GRASSO, M., HANNON, B., LIMBURG, K., NAEEM, S., O'NEILL, R. V., PARUELO, J., RASKIN, R. G., SUTTON, P. and VAN DEN BELT, M., 1997. The value of the world's ecosystem services and natural capital. Nature, vol. 387, p. 253-260.

COSTANZA, R., 2006. Nature: ecosystems without commodifying them. Nature, vol. 443, p. 749.

COWLING, RM., COSTANZA, R. and HIGGINS, SI., 1997. Services supplied by South African Fynbos ecosystems. In Daily, GC. (Ed). Nature's services: societal dependece on natural ecosystems. p. 345-362. Washington, DC: Island Press.

DA COSTA, MLMN., 2004. Diversidade biológica nos jardins botânicos brasileiros. Rio de Janeiro: Rede Brasileira de Jardins Botânicos. 99p.

DAILY, GC., 1997. Nature's services: societal dependence on natural systems. Washington DC: Island Press. $392 \mathrm{p}$.

DAILY, GC., SÖDERQVIST, T., ANIYAR, S., ARROW, K., DASGUPTA, P., EHRLICH, PR., FOLKE, C., JANSSON, AM., JANSSON, BO., KAUTSKY, N., LEVIN, S., LUBCHENCO, J., MÄLER, KG., SIMPSON, D., STARRETT, D., TILMAN, D. and WALKER, B., 2000. The Value of Nature and Nature of Value. Science, vol. 289, no 5478, p. 395-396.

DE GROOT, R., BRANDER, L., VAN DER PLOEG, S., COSTANZA, R., BERNARD, F., BRAAT, L., CHRISTIE, M., CROSSMAN, N., GHERMANDI, A., HEIN, L., HUSSAIN, S., KUMAR, P., MCVITTIE, A., PORTELA, R., RODRIGUEZ, LC., TEN BRINK, P. and VAN BEUKERING, P., 2012. Global estimates of the value of ecosystems and their services in monetary units. Ecosystem Services, vol. 1, p. 50-61.

DESALLE, R. and AMATO, G., 2004. The expansion of conservation genetics. Nature Reviews Genetics, vol. 5, p. $702-712$.

FERNANDES, GW., OKI, Y., SANCHEZ-AZOFEIFA, A., FACCION, G. and AMARO-ARRUDA, HC., 2011. Hail impact on leaves and endophytes of the endemic threatened Coccoloba cereifera (Polygonaceae). Plant Ecology, vol. 212, p. 1687-1697.

FRANKLIN, IR., 1980. Evolutionary change in small populations. In Soulé, ME. and Wilcox, BA. (Eds). Conservation Biology: an Evolutionary-Ecological Perspective. Sunderland: Sinauer. p. 135-140.
GANDARA, FB. and KAGEYAMA, PY., 1998. Indicadores de sustentabilidade de florestas naturais. Série Técnica Ipef, vol. 12 , no. 31 , p. $79-84$.

GIULIETTI, AM., PIRANI, JR. and HARLEY, RM., 1997. Espinhaço range region, eastern Brazil. In DAVIS, SD., HEYWOOD, VH., HERRERA-MACBRYDE, O., VILLA-LOBOS, J. and HAMILTON, AC. (Eds.). Centres of plant diversity: a guide and strategy for they conservation. p. 397-404. Cambridge: WWF/IUCN.

GIULIETTI, AM., MENEZES, NL., PIRANI, JR., MEGURO, M. and WANDERLEY, MGL., 1987. Flora da Serra do Cipó, Minas Gerais: caracterização e lista de espécies. Boletim de Botânica, vol. 9, p. 1-151.

GOLDING, J., GUSEWELL, S., KREFT, H., KUZEVANOV, VY., PARMENTIER, SLI. and PAUTASSO, M., 2010. Species-richness patterns of the living collections of the world's botanic gardens: a matter of socio-economics? Annals of Botany, vol. 105, p. 689-696.

HIGGINS, SI., TURPIE, JK., COSTANZA, R., COWLING, RM., LE MAITRE, DC., MARAIS, C. and MIDGLEY, GF., 1997. An ecological economic simulation model of mountain fynbos ecosystems - dynamics, valuation and management. Ecological Economics, vol. 22, p. 141-156.

Instituto Chico Mendes de Conservação da Biodiversidade ICMBio, 2009. Plano de Manejo do Parque Nacional da Serra do Cipó. Brasília: Instituto Chico Mendes de Conservação da Biodiversidade.

KLINK, CA. and MACHADO, RB., 2005. Conservation of the Brazilian Cerrado. Conservation Biology, vol. 19, no. 3, p. 707-713.

KLINK, CA., SANTOS, HG., CAMPARI, JRJS., MATSUMOTO, MH., FREITAS, GK. and BAUMGARTEN, L., 2008. Conservação dos recursos naturais em terras privadas: o papel das reservas legais no arranjo funcional das paisagens produtivas do bioma Cerrado. In SANO SM., ALMEIDA SP. and RIBEIRO JF. (Eds.). Cerrado: Ecologia e Flora, vol. 1, p. 399-406. Embrapa Cerrados.

KÖPPEN, W., 1931. Klimakarte der Erde. Grundriss der Klimakunde. 2nd ed. Berlin and Leipzig: Walter de Gruyter.

LOREAU, M., NAEEM, S. and INCHAUSTI, P., 2002. Biodiversity and ecosystem functioning: synthesis and perspectives. Oxford: Oxford University Press.

MADEIRA, JA. and FERNANDES, GW., 1999. Reproductive phenology of sympatric taxa of Chamaecrista (Leguminosae) in Serra do Cipó, Brazil. Journal of Tropical Ecology, vol. 15, p. 463-479.

MADEIRA, JA., RIBEIRO, KT., OLIVEIRA, MJRO., NASCIMENTO, JS. and PAIVA, CL., 2008. Distribuição espacial do esforço de pesquisa biológica na Serra do Cipó, Minas Gerais: subsídios ao manejo das unidades de conservação da região. Megadiversidade, vol. 4, no. 1-2, p. 233-247.

MENDONÇA, RC., FELFILI, JM., WALTER, BMT., SILVA JUNIOR, MC., REZENDE, AV., FILGUEIRAS, TS., NOGUEIRA, PE. and FAGG, CW., 2008. Flora vascular do bioma Cerrado: checklist com 12.356 espécies. In SANO SM., ALMEIDA SP. and RIBEIRO JF. (Eds.). Cerrado: Ecologia e Flora, vol. 2, p. 423-1279. Embrapa Cerrados.

Millennium Ecosystem Assessment - MA, 2003. Ecosystems and human well-being: a framework for assessment. Washington, DC: Island Press.

-, 2005. Ecosystems and human well-being: synthesis. Washington, DC: Island Press. 
MISTRETTA, O., RIESEBERG, LH. and ELIAS. TS., 1991. Botanical gardens and the preservation of biological diversity. Evolutionary Trends in Plants, vol. 5, p. 19-22.

NAEEM, S., CHAPIN III, FS., COSTANZA, R., EHRLICH, PR., GOLLEY, FB., HOOPER, DU., LAWTON, JH., O'NEILL, RV., MOONEY, HA., SALA, OE., SYMSTAD, AJ., TILMAN, D., 1999. Biodiversity and ecosystem functioning: Maintaining natural life support processes. Issues in Ecology Ecological Society of America, vol. 4, p. 1-11.

OKI, Y., FERNANDES, GW. and CORREA JUNIOR, A., 2008. Fungos: amigos ou inimigos? Ci ncia Hoje, vol. 42, no. 252 , p. 64-66.

PEREIRA, MCA., 1994. Estrutura das comunidades vegetais de afloramentos rochosos dos campos rupestres do Parque Nacional da Serra do Cipó, MG. Belo Horizonte: Universidade Federal de Minas Gerais. 163p. Dissertação de Mestrado em Ecologia, Conservação e Manejo de Vida Silvestre.

RANIERI, BD., LANA, TC., NEGREIROS, D., ARA JO, LM. and FERNANDES, GW., 2003. Germinação de sementes de Lavoisiera cordata cogn. e Lavoisiera francavillana cogn. (Melastomataceae), espécies simpátricas da Serra do Cipó, Brasil. Acta Botanica Brasilica, vol. 17, no. 4, p. 523-530.

SANO, EE., JESUS, ET. and BEZERRA, HS., 2001. Uso de um sistema de informa o geogr fica para quantifica o de reas remanescentes do Cerrado. Comunicado Técnico 62. Planaltina: Embrapa Cerrados.
Convention on Biological Diversity - CBD, 2007. An exploration of tools and methodologies for valuation of biodiversity and biodiversity resources and functions. Technical Series n 28. Montreal: Convention on Biological Diversity.

STEVENS, AD., 2007. Botanical gardens and their role in ex situ conservation and research. Phyton - Annales Rei Botanicae, vol. 46, p. 211-214.

United Nations Environment Programme - UNEP, 2007. Biodiversity and poverty reduction the importance of biodiversity for ecosystem services. Cambridge: United Nations Environment Programme World Conservation Monitoring Centre (UNEP-WCMC).

VIANA, LR., FERNANDES, GW. and SILVA, CA., 2005. Ecological road threatens endemic Brazilian plant with extinction. Plant Talk, vol. 41, p. 15.

VENTURA, CP., OLIVEIRA, AB. and BRAGA, FC., 2007. Antimicrobial activity of Trembleya laniflora, Xyris platystachia and Xyris pterygoblephara. Brazilian Journal of Pharmacognosy, vol. 17, no. 1, p. 17-22.

ZAPPI, DC., LUCAS, E., STANNARD, BL., LUGHADHA, E., PIRANI, JR., QUEIROZ, LP., ATKINS, S., HIND, N., GIULIETTI, AM., HARLEY, RM., MAYO, SJ. and CARVALHO, AM., 2002. Biodiversidade e conservação na Chapada Diamantina, Bahia: Catolés, um estudo de caso. In ARA JO, EL., MOURA, AN., SAMPAIO, EVSB., GESTIN RI, LMS. and CARNEIRO, JMT. (Eds). Biodiversidade, conserva o e uso sustent vel da flora do Brasil. Recife: SBB/UFRPE. p. 87-89. 


\section{Appendices}

Appendix 1 - Cost associated with acquisition of one native plant specimen in Serra do Cipó related to 2010 .

\begin{tabular}{|c|c|c|c|c|c|}
\hline Item & Quantity & Unit cost (US\$) & $\begin{array}{c}\text { Total cost } \\
\left(\text { US\$ year }{ }^{-1}\right)\end{array}$ & $\begin{array}{c}\mathrm{N}^{0} \text { of } \\
\text { specimens }\end{array}$ & $\begin{array}{c}\text { Cost per } \\
\text { specimen } \\
\left(\mathrm{US} \$ \text { year }^{-1}\right)\end{array}$ \\
\hline Car rental $^{\mathrm{a}}$ & 24 days & 117.48 & $2,819.43$ & 268 & 10.52 \\
\hline Fuel $^{b}$ & 160 liters & 1.51 & 241.23 & 268 & 0.90 \\
\hline $\begin{array}{c}\text { Food and } \\
\text { accommodation }^{c}\end{array}$ & 96 costs/day & 62.82 & $6,030.86$ & 268 & 22.50 \\
\hline Total & & & & & 30.86 \\
\hline
\end{tabular}

a 3 days/month, 8 months/year. $\mathrm{N}^{\mathrm{o}}$ of specimen/day $=11.5$.

${ }^{\mathrm{b}} 12$ litres/month, 8 months/year. $\mathrm{N}^{\mathrm{o}}$ of specimen/day $=11.5$.

${ }^{\mathrm{c}} 4$ technicians, 3 days/month, 8 months/year. $\mathrm{N}^{\mathrm{o}}$ of specimen/day $=11.5$.

Source: BG-ZBF database; personal information (staff). 
Appendix 2 - Costs associated to the physical structure used for packaging plants in the living collections of the BG-ZBF related to 2010.

\begin{tabular}{lccc}
\hline Item & $\begin{array}{c}\text { Total cost } \\
\text { (US\$ year }^{-1} \text { ) }\end{array}$ & Lifetime & $\begin{array}{c}\text { Cost per } \\
\text { specimen }^{-1} \\
\text { (US\$ year } \text { ( }^{-1}\end{array}$ \\
\hline $\begin{array}{c}\text { Nurseries with } \\
\text { irrigation system }\end{array}$ & $82,924.29$ & 20 years & 1.26 \\
\hline Total & & 1.26 \\
\hline
\end{tabular}

${ }^{\mathrm{a} C}$ Current structure.

Source: BG-ZBF database.

Appendix 3 - Costs related to the areas associated with technical/administrative activities and nurseries for living collections related to 2010 .

\begin{tabular}{|c|c|c|c|c|c|}
\hline Utilisation & $\begin{array}{c}\text { Area } \\
\left(\mathrm{m}^{2}\right)\end{array}$ & $\begin{array}{c}\text { Unit cost } \\
(\text { US\$ month } \\
\end{array}$ & $\begin{array}{c}\text { Total cost } \\
(\text { US\$ month }\end{array}$ & $\begin{array}{c}\text { Total cost } \\
(\text { US\$ year }\end{array}$ & $\begin{array}{c}\text { Cost per } \\
\text { specimen } \\
\text { (US\$ year } \\
{ }_{1} \text { ) }\end{array}$ \\
\hline $\begin{array}{c}\text { Technical } \\
\text { Administrative }^{\mathrm{a}}\end{array}$ & 103.8 & 3.96 & 410.81 & $4,929.77$ & 1.49 \\
\hline Nurseries $^{\mathrm{b}}$ & 1,500 & 1.54 & $2,308.69$ & $27,704.25$ & 8.40 \\
\hline Total & & & & & $\begin{array}{l}9.89 \\
\end{array}$ \\
\hline
\end{tabular}

${ }^{a}$ Cost related to the rental rate for commercial properties near the BG-ZBF. We assumed that the rental rate is $0.7 \%$ of the property value and that the value of $\mathrm{m}^{2}$ is US\$529.41. The cost of the building was not considered.

${ }^{b}$ Cost related to the property rental near the BG-ZBF. We assumed that the rental rate is $0.7 \%$ of the property value and that the $\mathrm{m}^{2}$ value is US\$ 205.88 .

Obs: Tax costs were not considered. 
Appendix 4 - Expenses for the acquisition of permanent materials in the BG-ZBF for 2010.

\begin{tabular}{|c|c|c|c|c|c|c|}
\hline Sector & Item & $\begin{array}{c}\text { Cost } \\
(\mathbf{U S \$})^{\mathrm{a}}\end{array}$ & $\begin{array}{l}\text { Lifetime } \\
\text { (year) }\end{array}$ & $\begin{array}{c}\text { Total cost } \\
\left(\text { US\$ year }{ }^{-1}\right)\end{array}$ & $\begin{array}{c}\text { Cost per } \\
\text { specimen } \\
\left(\text { US\$ year }{ }^{-1}\right)\end{array}$ & $\begin{array}{c}\text { Additional } \\
\text { information }\end{array}$ \\
\hline \multirow{3}{*}{$\begin{array}{l}\text { Applied } \\
\text { Botany }\end{array}$} & Furniture & $2,674.91$ & 10 & 267.49 & 0.08 & $100 \%$ \\
\hline & $\begin{array}{l}\text { Electronic } \\
\text { equipment }\end{array}$ & $15,162.69$ & 5 & 3032.54 & 0.92 & $100 \%$ \\
\hline & $\begin{array}{l}\text { Other } \\
\text { equipment }\end{array}$ & 892.31 & $5-10$ & 141.73 & 0.04 & $100 \%$ \\
\hline \multirow[t]{2}{*}{ Trainees } & Furniture & 153.79 & 10 & 15.38 & 0.00 & $100 \%$ \\
\hline & $\begin{array}{l}\text { Electronic } \\
\text { equipment }\end{array}$ & 28.77 & 5 & 5.75 & 0.00 & $100 \%$ \\
\hline \multirow[t]{2}{*}{ Laboratory } & Furniture & 804.62 & 10 & 26.55 & 0.01 & $100 \%$ \\
\hline & Equipment & $4,184.19$ & $10-15$ & 86.32 & 0.03 & $100 \%$ \\
\hline \multirow[t]{2}{*}{ Boardroom } & Furniture & $1,594.66$ & 10 & 52.62 & 0.02 & $33.3 \%$ \\
\hline & $\begin{array}{l}\text { Electronic } \\
\text { equipment }\end{array}$ & $2,522.51$ & 5 & 166.49 & 0.05 & $33.3 \%$ \\
\hline \multirow{3}{*}{$\begin{array}{l}\text { Technicians } \\
\text { room }\end{array}$} & Furniture & 674.95 & 10 & 22.27 & 0.01 & $33.3 \%$ \\
\hline & $\begin{array}{l}\text { Electronic } \\
\text { equipment }\end{array}$ & $3,000.73$ & 5 & 198.05 & 0.06 & $33.3 \%$ \\
\hline & $\begin{array}{l}\text { Others } \\
\text { equipment }\end{array}$ & $2,289.34$ & $5-10$ & 79.79 & 0.02 & $33.3 \%$ \\
\hline Meeting room & Furniture & 377.85 & 10 & 12.47 & 0.00 & $33.3 \%$ \\
\hline \multirow[t]{3}{*}{ Accessory } & Furniture & 808.36 & 10 & 26.68 & 0.01 & $33.3 \%$ \\
\hline & $\begin{array}{l}\text { Electronic } \\
\text { equipment }\end{array}$ & $7,062.07$ & 5 & 466.10 & 0.14 & $33.3 \%$ \\
\hline & $\begin{array}{l}\text { Others } \\
\text { equipment }\end{array}$ & 555.34 & 20 & 9.16 & 0.00 & $33.3 \%$ \\
\hline \multirow[t]{3}{*}{ Refectory } & Furniture & 283.95 & 10 & 9.37 & 0.00 & $33.3 \%$ \\
\hline & $\begin{array}{l}\text { Electronic } \\
\text { equipment }\end{array}$ & 266.36 & 5 & 17.58 & 0.01 & $33.3 \%$ \\
\hline & $\begin{array}{l}\text { Others } \\
\text { equipment }\end{array}$ & 231.18 & 5 & 15.26 & 0.00 & $33.3 \%$ \\
\hline \multirow[t]{2}{*}{ Kitchen } & Furniture & 220.88 & 10 & 7.29 & 0.00 & $33.3 \%$ \\
\hline & $\begin{array}{l}\text { Electronic } \\
\text { equipment }\end{array}$ & 804.11 & 5 & 53.07 & 0.02 & $33.3 \%$ \\
\hline Lobby & $\begin{array}{l}\text { Electronic } \\
\text { equipment }\end{array}$ & $2,774.19$ & 5 & 183.10 & 0.06 & $33.3 \%$ \\
\hline \multirow[t]{3}{*}{ Reception } & Furniture & 244.59 & 10 & 8.07 & 0.00 & $33.3 \%$ \\
\hline & $\begin{array}{l}\text { Electronic } \\
\text { equipment }\end{array}$ & $5,071.36$ & 5 & 304.45 & 0.09 & $33.3 \%$ \\
\hline & $\begin{array}{l}\text { Others } \\
\text { equipment }\end{array}$ & 64.83 & 15 & 1.43 & 0.00 & $33.3 \%$ \\
\hline Total & & & & & 1.58 & \\
\hline
\end{tabular}


${ }^{a}$ Refers to $80 \%$ of the total expenditures. This rate $(80 \%)$ was chosen because it represents the amount of resources allocated to the living collections of the BG-ZBF. The remaining $20 \%$ was allocated to the reference collections (e.g., herbarium, fruit collection, seed collection) and was not considered in this study.

${ }^{b}$ We used $100 \%$ of the calculated value for costs directly associated with the Applied Botany Section. Other expenses were calculated at $33.3 \%$ of their total expenditure. The BG-ZBF has three departments, and only one is responsible for living collections.

Source: BG-ZBF database. 
Appendix 5 - Costs related to the supplies costs for the living collections of the BG-ZBF for 2010 .

\begin{tabular}{|c|c|c|c|}
\hline Item & $\begin{array}{c}\text { Total cost } \\
\left(\text { US\$ year }{ }^{-1}\right)\end{array}$ & $\begin{array}{l}\text { Cost per } \\
\text { specimen } \\
\text { (US\$ } \\
\text { year }^{-1} \text { ) }\end{array}$ & $\begin{array}{c}\text { Additional } \\
\text { information }\end{array}$ \\
\hline Computer materials & 67.85 & 0.02 & $100 \%$ \\
\hline Electronic materials & 69.81 & 0.02 & $100 \%$ \\
\hline Cleaning supplies & 243.60 & 0.07 & $100 \%$ \\
\hline $\begin{array}{l}\text { Fertilisers, } \\
\text { Pesticides and } \\
\text { Substrates }\end{array}$ & 876.24 & 0.27 & $100 \%$ \\
\hline $\begin{array}{c}\text { Laboratory - } \\
\text { Chemicals products }\end{array}$ & 298.09 & 0.09 & $100 \%$ \\
\hline Ropes/Chains & 15.58 & 0.00 & $100 \%$ \\
\hline $\begin{array}{l}\text { Construction } \\
\text { materials }\end{array}$ & 458.39 & 0.14 & $100 \%$ \\
\hline Medicines & 499.50 & 0.15 & $100 \%$ \\
\hline Safety equipment & 319.30 & 0.10 & $100 \%$ \\
\hline $\begin{array}{l}\text { Wrapping and } \\
\text { packaging }\end{array}$ & 169.37 & 0.05 & $100 \%$ \\
\hline Office supplies & 287.76 & 0.09 & $100 \%$ \\
\hline Manual tools & 215.52 & 0.07 & $100 \%$ \\
\hline $\begin{array}{c}\text { Communication } \\
\text { and identification } \\
\text { items }\end{array}$ & 110.57 & 0.03 & $100 \%$ \\
\hline Garden tools & $2,147.40$ & 0.65 & $100 \%$ \\
\hline Home materials & 273.64 & 0.08 & $100 \%$ \\
\hline $\begin{array}{l}\text { Refectory and } \\
\text { kitchen }\end{array}$ & 19.85 & 0.01 & $100 \%$ \\
\hline $\begin{array}{c}\text { Processing } \\
\text { materials } \\
\text { Metallic }\end{array}$ & 19.00 & 0.01 & $100 \%$ \\
\hline uniforms & 845.54 & 0.26 & $100 \%$ \\
\hline $\begin{array}{l}\text { Bibliographic } \\
\text { collections }\end{array}$ & 644.46 & 0.20 & $33.3 \%$ \\
\hline Total & & 2.30 & \\
\hline
\end{tabular}


${ }^{a}$ Refers to $80 \%$ of the total expenditures. This rate $(80 \%)$ was chosen because it represents the amount of resources allocated to the living collections of the BG-ZBF. The remaining $20 \%$ was allocated to the reference collections and was not considered in this study.

Source: BG-ZBF database. 
Appendix 6 - Human resource costs associated with the living collections at the BG-ZBF for 2010.

\begin{tabular}{|c|c|c|c|c|}
\hline Post & Quantity & $\begin{array}{l}\text { Unit cost } \\
(\text { US\$ } \\
\left.\text { month }^{-1}\right)^{b}\end{array}$ & $\begin{array}{c}\text { Total cost } \\
\left(\text { US\$ year }{ }^{-1}\right)\end{array}$ & $\begin{array}{c}\text { Cost per } \\
\text { specimen } \\
\text { (US\$ year } \\
1 \text { ) }\end{array}$ \\
\hline Director $^{\mathrm{a}}$ & 1 & $1,172.67$ & $14,072.00$ & 4.26 \\
\hline Biologist & 4 & $2,035.41$ & $97,699.89$ & 29.61 \\
\hline Gardner & 4 & $1,010.17$ & $48,488.09$ & 14.69 \\
\hline $\begin{array}{l}\text { Gardner } \\
\text { assistant }\end{array}$ & 2 & 712.86 & $17,108.58$ & 5.18 \\
\hline Trainee & 1 & 293.40 & $3,520.81$ & 1.07 \\
\hline $\begin{array}{l}\text { Administrative } \\
\text { assistant }^{\mathrm{a}}\end{array}$ & 2 & 310.11 & $7,442.72$ & 2.26 \\
\hline $\begin{array}{c}\text { General } \\
\text { assistant }^{\mathrm{a}}\end{array}$ & 2 & 475.24 & $5,702.86$ & 1.73 \\
\hline
\end{tabular}

${ }^{\mathrm{a}}$ Professional shared with the other two departments of the BG-ZBF. When this occurred, onethird of the total salary was calculated.

${ }^{b}$ Refers to $80 \%$ of the total expenditures. This rate $(80 \%)$ was chosen as it represents the amount of resources allocated to the living collections of the BG-ZBF. The remaining $20 \%$ was allocated to the reference collections and was not considered in this study.

Source: BG-ZBF database 
Appendix 7 - Electricity, communication (internet and telephone) and water consumption costs associated with the living collections of the BG-ZBF for 2010.

\begin{tabular}{cccc}
\hline Category & $\begin{array}{c}\text { Total cost } \\
\left.\text { (US\$ month }^{-1}\right)^{\mathrm{a}}\end{array}$ & $\begin{array}{c}\text { Total cost } \\
\text { (US\$ year }^{-1} \text { ) }\end{array}$ & $\begin{array}{c}\text { Cost per } \\
\text { specimen }^{\text {(US\$ year }} \mathbf{~}^{-1} \text { ) }\end{array}$ \\
\hline Electricity & 241.23 & $2,894.81$ & 0.88 \\
Communication & 75.39 & 904.63 & 0.27 \\
Water & 289.65 & $3,475.75$ & 1.05 \\
\hline
\end{tabular}

${ }^{a}$ Refers to $80 \%$ of the total expenditures. This rate $(80 \%)$ was chosen as it represents the amount of resources allocated to the living collections of the BG-ZBF. The remaining $20 \%$ was allocated to the reference collections and was not considered in this study.

Source: BG-ZBF database. 
Appendix 8 - Taxonomic groups included in the valuation of the plant diversity storage service provided by Serra do Cipó ecosystems.

\begin{tabular}{ccccccc}
\cline { 3 - 6 } Taxa & $\begin{array}{c}\text { No of } \\
\text { species }\end{array}$ & $\begin{array}{c}\text { Endemic }- \\
\text { Serra do } \\
\text { Cipó }\end{array}$ & $\begin{array}{c}\text { Endemic }- \\
\text { Espinhaço } \\
\text { Range }\end{array}$ & $\begin{array}{c}\text { Threatened } \\
- \text { MG state }\end{array}$ & $\begin{array}{c}\text { Non } \\
\text { endemic } \\
\text { and not } \\
\text { threatened }\end{array}$ \\
\hline Bryopsida & 20 & 0 & 0 & 0 & 20 \\
Coniferopsida & 2 & 0 & 0 & 0 & 2 \\
Dicotyledonea & 1,465 & 20 & 55 & 73 & 1,337 \\
Lycopsida & 5 & 0 & 0 & 0 & 5 \\
Monocotiledoneae & 609 & 51 & 30 & 40 & 539 \\
Pteropsida & 56 & 1 & 1 & 0 & 55 \\
Total & 2,157 & 72 & 86 & 113 & 1,958 \\
\hline Souryyyyy
\end{tabular}

Source: Modified from Madeira et al. (2008). 